\title{
Groundwater Quality in the Northern Atlantic Coastal Plain Aquifer System, Eastern United States
}

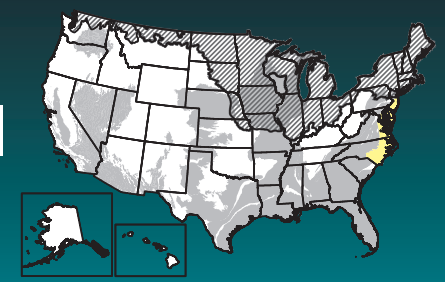

Groundwater provides nearly $\mathbf{5 0}$ percent of the Nation's drinking water. To help protect this vital resource, the U.S. Geological Survey (USGS) National Water-Quality Assessment (NAWQA) Project assesses groundwater quality in aquifers that are important sources of drinking water (Burow and Belitz, 2014). The Northern Atlantic Coastal Plain aquifer system constitutes one of the important areas being evaluated.

\section{Background}

The Northern Atlantic Coastal Plain (NACP) aquifer system underlies an area with a population of more than 21 million people in six States. The NACP aquifer system ranks seventh in the Nation as a source of groundwater for public supply and fourth for domestic supply, and about 930 million gallons per day are pumped for those uses (Arnold and others, 2016). Land use overlying the aquifer system is mostly undeveloped (62 percent), agricultural (24 percent), and urban land (14 percent).

The Northern Atlantic Coastal Plain aquifer system is composed of unconsolidated to partly consolidated sediments (Denver and others, 2014; Masterson and others, 2015). These sedimentary layers progressively thicken and deepen seaward from the Fall Line, to the Atlantic Coast, where sediments reach a maximum thickness of about 10,000 feet in North Carolina. A series of clay and silt confining layers separate 10 regional aquifers that are used for water supply (Masterson and others, 2015). Recharge enters the aquifer mostly from the outcrop and subcrop areas in the landward part of the aquifer system, but some recharge comes from downward leakage through confining units.

The Piney Point-Castle Hayne (PP) aquifers and the Potomac-Magothy (PM) aquifers (Magothy, Potomac-Patapsco, and Potomac-Patuxent aquifers) are aquifers in the NACP that were selected

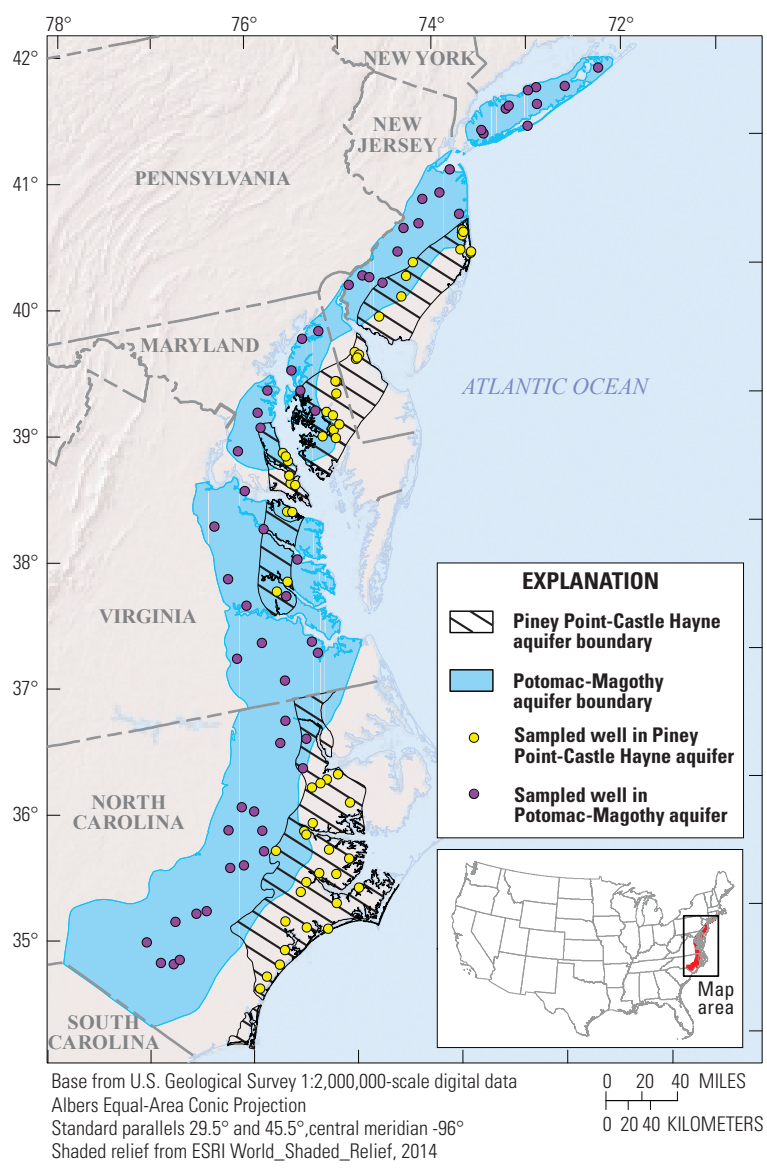
for study because of their importance as sources of public supply (Masterson and others, 2015). Groundwater for public supply is often obtained from a relatively deep zone in these aquifers. In the PP aquifers, the top of this zone is typically 200 to 350 feet beneath the land surface, and it is typically 50 to 250 feet thick. In the PM aquifers, the top of this zone is typically 350 to 500 feet beneath the land surface, and it is typically 300 to 1,000 feet thick. Groundwater quality in the PP and PM aquifers was evaluated by sampling 119 spatially distributed public-supply wells in these two aquifers. For this discussion, the study area is defined as the depth zone used for public supply in the NACP aquifer system. Water-quality data, collected from a set of spatially distributed wells, were used to estimate the percentage of the study area with concentrations that are high, moderate, and low with respect to constituent benchmarks. The accuracy of the estimates depends upon the distribution and number of wells, not on the size of the area (Belitz and others, 2010). Samples were analyzed for a large number of water-quality constituents derived from natural and human sources.

\section{Overview of Water Quality}



\section{Organic constituents}



CONSTITUENT CONCENTRATIONS

$\bigcirc$ High $\bigcirc$ Moderate $\bigcirc$ Low or not detected

Values are a percentage of the study area with concentrations in the three specified categories. Percentages might not sum to 100 because of rounding.

Principal Aquifer Studies are designed to evaluate groundwater used for public supply prior to any treatment. Groundwater quality is assessed by comparing concentrations to benchmarks established for drinking-water quality. Benchmarks and definitions of high, moderate, and low concentrations are discussed in the inset box on page 3 .

Many inorganic constituents are naturally present in groundwater. The concentrations of inorganic constituents can be affected by natural processes as well as by human activities. One or more inorganic constituents were detected at high concentrations in about 4 percent of the study area and at moderate concentrations in about 18 percent.

Organic constituents derived from human activities are used in household, business, industrial, and agricultural products. They can enter the environment through normal usage, spills, or improper disposal. Organic constituents were not detected at high concentrations in the study area and were detected at moderate concentrations in about 2 percent of the study area. 


\section{Results: Groundwater Quality at the Depth Zone Used for Public Supply in the Northern Atlantic Coastal Plain Aquifers}

\section{INORGANIC CONSTITUENTS}
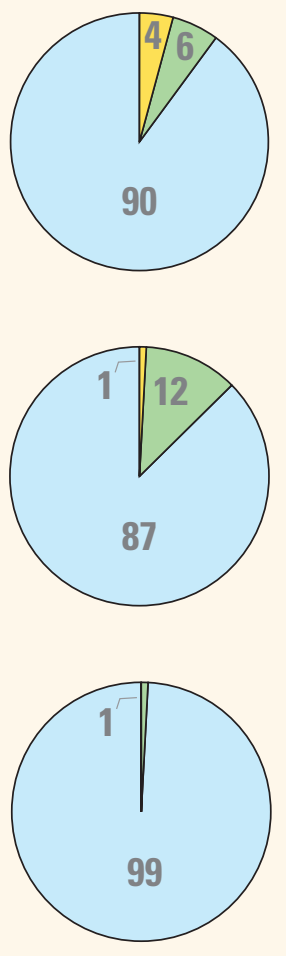

\section{Radioactive constituents}

\section{Nutrients}

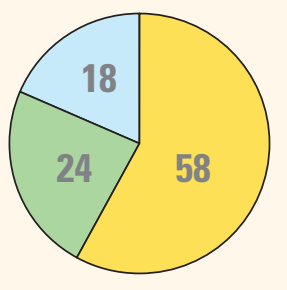

\section{Inorganic Constituents with Human-Health Benchmarks}

Trace elements and major and minor ions are naturally present in the minerals of rocks, soils and sediments and in the water that comes into contact with those materials. Samples were analyzed for 34 trace elements and major and minor ions, of which 19 have human-health benchmarks. Constituents from this group were detected at high concentrations in about 4 percent of the study area (the depth zone used for public supply) and at moderate concentrations in about 6 percent. Fluoride, arsenic, and manganese were the only constituents in this group that were detected at high concentrations.

Radioactivity is the release of energy or energetic particles during spontaneous decay of unstable atoms. Humans are continuously exposed to small amounts of natural radioactivity. Most of the radioactivity in groundwater comes from the decay of isotopes of uranium and thorium that are naturally present in minerals in aquifer materials. Samples were analyzed for eight radioactive constituents, of which four have human-health benchmarks. Radioactive constituents were present at high levels in about 1 percent of the study area and at moderate levels in about 12 percent. Gross alpha activity was the only constituent that was present at high concentrations.

Nutrients are naturally present at low concentrations in groundwater; high and moderate concentrations (relative to human-health benchmarks) generally result from human activities. Samples were analyzed for five nutrients, of which two have human-health benchmarks. Common sources of nutrients, aside from soils, include fertilizer applied to crops and landscaping, seepage from septic systems, and human and animal waste. No nutrients were detected at high concentrations in the study area. Nitrate was detected at moderate concentrations in about 1 percent of the study area.

\section{Inorganic Constituents and Field Measurements with Non-Health Benchmarks}

(Not included in water-quality overview charts shown on the front page)

Some constituents affect the aesthetic properties of water, such as taste, color, and odor, or can create nuisance problems, such as staining and scaling. The benchmarks used for these constituents were non-regulatory secondary maximum contaminant level (SMCL) benchmarks established for public drinking water. Some constituents, such as fluoride and manganese, have human-health benchmarks and SMCLs. Samples were analyzed for 11 constituents that have SMCLs. One or more of these were present at high concentrations or values relative to the SMCL in 58 percent of the study area and at moderate concentrations in about 24 percent.

The total dissolved solids (TDS) concentration is a measure of the salinity of the groundwater, and all water naturally contains TDS as a result of the weathering and dissolution of minerals in rocks and sediments. Concentrations of TDS can be high because of natural factors or as a result of human activities such as applications of road salt, fertilizers, or other chemicals to the land surface in urban or agricultural areas. TDS concentrations were high in about 12 percent of the study area. Chloride and fluoride also were high in 2 and 5 percent of the study area, respectively.

Anoxic conditions in groundwater (low amounts of dissolved oxygen) can result in release of iron and manganese in minerals to the groundwater. Iron and manganese were present at high concentrations in about 32 and 16 percent of the study area, respectively.

In some areas, the $\mathrm{pH}$ of the groundwater was not in the SMCL range of 6.5 to 8.5 ; most samples had $\mathrm{pH}$ values less than 6.5 , which is considered acidic and potentially corrosive. Low $\mathrm{pH}$ groundwater was most commonly observed in the northern Potomac-Magothy aquifers, where more than half the well samples had $\mathrm{pH}$ values less than 6.5. 


\section{Results: Groundwater Quality at the Depth Zone Used for Public Supply in the Northern Atlantic Coastal Plain Aquifers}

\section{ORGANIC CONSTITUENTS}

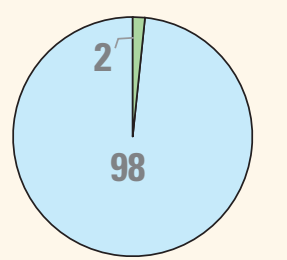

VOCs

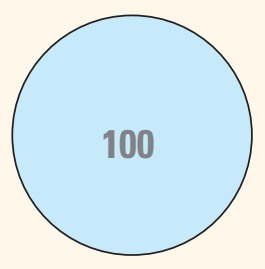

\section{Volatile Organic Compounds with Human-Health Benchmarks}

Volatile organic compounds (VOCs) are present in many household, commercial, industrial, and agricultural products and are characterized by their tendency to volatilize (evaporate). Samples were analyzed for 90 VOCs, of which 38 have humanhealth benchmarks. No VOCs were detected at high concentrations in the study area; VOCs were detected at moderate concentrations in about 2 percent of the study area. Compounds detected at moderate concentrations were the disinfection by-products dibromochloromethane and bromoform and the solvents trichloroethylene (TCE) and 1,1-dichloroethylene.

\section{Pesticide Compounds with Human-Health Benchmarks}

Pesticides, including herbicides, insecticides, and fumigants, are applied to crops, gardens and lawns, around buildings, and along roads to help control unwanted vegetation (weeds), insects, fungi, and other pests. Samples were analyzed for 227 pesticide compounds (pesticides and their breakdown products), of which 119 have human-health benchmarks. Pesticides were not detected at high or moderate concentrations in the study area.

\section{BENCHMARKS FOR EVALUATING GROUNDWATER QUALITY}

The USGS NAWQA Project uses benchmarks established for drinking water to provide context for evaluating the quality of untreated groundwater. The quality of water received by consumers can be different, because after withdrawal, groundwater may be treated prior to delivery. Federal regulatory benchmarks for protecting human health are used for this evaluation of water quality when available. Otherwise, nonregulatory human-health benchmarks and non-regulatory aesthetic benchmarks are used. Not all constituents analyzed have benchmarks and thus are not considered in this context. Out of 55 inorganic constituents and properties and 317 organic constituents, 24 and 157, respectively, have human-health benchmarks.

Concentrations are considered high if they are greater than a human-health benchmark (Toccalino and others, 2014) or SMCL. For inorganic constituents, concentrations are moderate if they are greater than one-half of a benchmark. For organic constituents, concentrations are moderate if they are greater than one-tenth of a benchmark; this lower threshold is used because organic constituents are generally less prevalent and have smaller concentrations relative to benchmarks than inorganic constituents (Toccalino and others, 2004).

\section{Benchmarks Type and Value for Selected Constituents}

This table presents benchmarks for those constituents detected at high concentrations in the the Northern Atlantic Coastal Plain aquifer system. Benchmark types are regulatory U.S. Environmental Protection Agency maximum contaminant levels (MCLs), non-regulatory health-based screening levels (HBSLs), and non-regulatory secondary maximum contaminant levels (SMCLs).

[Abbreviations: ppb, parts per billion or micrograms per liter $(\mu \mathrm{g} / \mathrm{L})$; ppm, parts per million or milligrams per liter $(\mathrm{mg} / \mathrm{L})$; $\mathrm{pCi} / \mathrm{L}$, picocuries per liter].

\begin{tabular}{|c|c|c|c|c|c|}
\hline \multirow{2}{*}{ Constituent } & \multicolumn{2}{|c|}{ Benchmark } & \multirow{2}{*}{ Constituent } & \multicolumn{2}{|c|}{ Benchmark } \\
\hline & Type & Value & & Type & Value \\
\hline Arsenic & MCL & $10 \mathrm{ppb}$ & Total dissolved solids (TDS) & SMCL & $500 \mathrm{ppm}$ \\
\hline Manganese & HBSL & $300 \mathrm{ppb}$ & Manganese & SMCL & $50 \mathrm{ppb}$ \\
\hline Gross alpha activity & MCL & $15 \mathrm{pCi} / \mathrm{L}$ & Chloride & SMCL & $250 \mathrm{ppm}$ \\
\hline Fluoride & MCL & $4 \mathrm{ppm}$ & Fluoride & SMCL & $2 \mathrm{ppm}$ \\
\hline Iron & SMCL & $300 \mathrm{ppb}$ & $\mathrm{pH}$ & SMCL & $6.5-8.5$ \\
\hline
\end{tabular}




\section{Constituents with High Concentration Vary by Aquifer and Region}

Two confined aquifers in two geographic locations were sampled in the NACP: the PM and PP aquifers in the northern part of the NACP and their lateral equivalents in the southern part of the NACP. High concentrations of inorganic constituents, including arsenic, manganese, gross alpha activity, and fluoride, varied both by aquifer and geographic location. In the northern area, high concentrations of arsenic were detected in the PP aquifer, and high concentrations of manganese and gross alpha activity were detected in the PM aquifer. In the southern area, high concentrations of fluoride were detected in the PM aquifer. Organic constituents were not detected at high or moderate concentrations in any of the aquifers. Constituents with secondary benchmarks, including dissolved solids, iron, and chloride, were detected at high and moderate concentrations in all four areas.

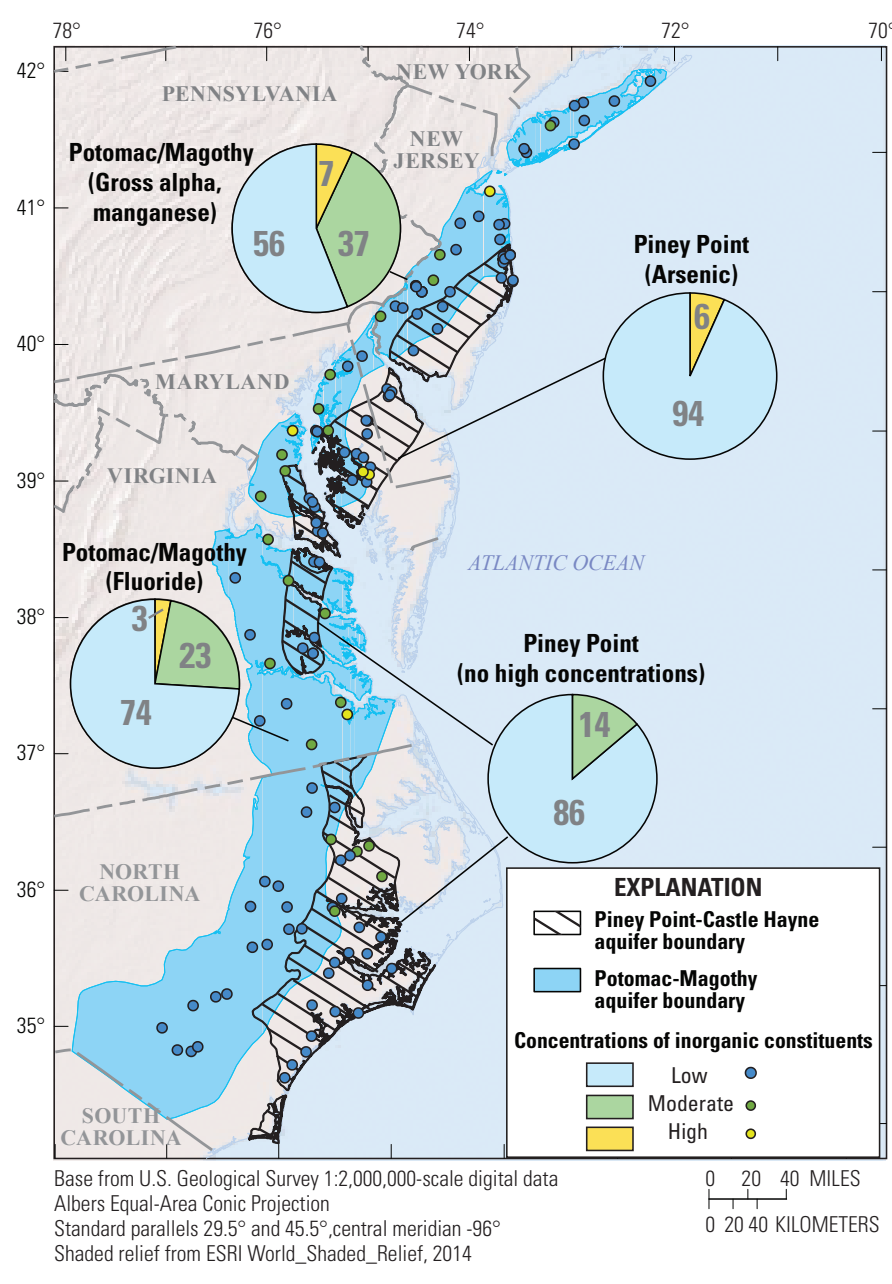

By Bruce Lindsey and Kenneth Belitz

\section{SELECTED REFERENCES}

Arnold, T.L., DeSimone, L.A., Bexfield, L.M., Lindsey, B.D., Barlow, J.R., Kulongoski, J.T., Musgrove, M., Kingsbury, J.A., and Belitz, K., 2016, Groundwater quality data from the National Water-Quality Assessment Program, May 2012 through December 2013: U.S. Geological Survey Data Series 997, 56 p., http://dx.doi.org/10.3133/ds997.

Belitz, K., Jurgens, B., Landon, M.K., Fram, M.S., and Johnson, T., 2010, Estimation of aquifer scale proportion using equal area grids: Assessment of regional scale groundwater quality: Water Resources Research., v. 46, 14 p., http://dx.doi.org/10.1029/2010WR009321.

Burow, K.R., and Belitz, K., 2014, Groundwater studies-Principal aquifer surveys: U.S. Geological Survey Fact Sheet 2014-3024, 2 p., http://dx.doi.org/10.3133/fs20143024.

Denver, J.M., Ator, S.W., Fischer, J.M., Harned, D.C., Schubert, Christopher, and Szabo, Zoltan, 2014, The quality of our Nation's waters - Water quality in the Northern Atlantic Coastal Plain surficial aquifer system, Delaware, Maryland, New Jersey, New York, North Carolina, and Virginia, 1988-2009: U.S. Geological Survey Circular 1353, 88 p., http://dx.doi.org/10.3133/cir1353

DeSimone, L.A., McMahon, P.B., and Rosen, M.R., 2014, The quality of our Nation's waters-Water quality in Principal Aquifers of the United States, 1991-2010: U.S. Geological Survey Circular 1360, 151 p., http://dx.doi.org/10.3133/cir1360.

Masterson, J.P., Pope, J.P., Monti, Jack, Jr., Nardi, M.R., Finkelstein, J.S., and McCoy, K.J., 2015, Hydrogeology and hydrologic conditions of the Northern Atlantic Coastal Plain aquifer system from Long Island, New York, to North Carolina (ver. 1.1, September 2015): U.S. Geological Survey Scientific Investigations Report 2013-5133, 76 p., http://dx.doi.org/10.3133/sir20135133.

Toccalino, P.L., Norman, J.E., Phillips, R.H., Kauffman, L.J., Stackelberg, P.E., Nowell, L.H., Krietzman, S.J., and Post, G.B., 2004, Application of health-based screening levels to ground-water quality data in a state-scale pilot effort: U.S. Geological Survey Scientific Investigations Report 2004-5174, 64 p., http://pubs.usgs.gov/sir/2004/5174/.

Toccalino, P.L., Norman, J.E., and Schoephoester, K.M., 2014, Health-based screening levels for evaluating water-quality data, http://water.usgs.gov/nawqa/HBSL, doi:10.5066/F71C1TWP.

\section{Principal Aquifer Studies}

The USGS NAWQA Project has been assessing the quality of groundwater since 1991. The NAWQA studies include Land Use Studies (LUS), Major Aquifer Studies (MAS), and Principal Aquifer Studies (PAS). The three study types are based on sampling networks of wells distributed across an area of interest. The LUS networks typically consist of observation wells that are relatively shallow; MAS networks typically consist of domestic-supply wells that are intermediate in depth; and PAS networks typically consist of public-supply wells that are relatively deep. A national synthesis of shallow and intermediate depth groundwater quality was reported by DeSimone and others (2014), and a regional synthesis of shallow and intermediate depth groundwater quality from the NACP aquifer system was reported by Denver and others (2014). This fact sheet provides a summary of PAS data for 119 public-supply wells sampled in 2013 in the NACP aquifer system (data available in Arnold and others, 2016).

The PAS assessments like this one allow for the comparison of constituent concentrations in untreated groundwater with benchmarks established for the protection of human health and for aesthetic qualities of drinking water and also provide a basis for comparison of groundwater quality among the principal aquifers.

The data collected by NAWQA include chemical analyses generally not available as part of regulatory compliance monitoring, including measurements at concentrations much lower than the levels used as human-health benchmarks and measurements of constituents that can be used to trace the sources and movement of groundwater.

\section{For more information}

Technical reports and hydrologic data collected for the NAWQA Project may be obtained from:

\section{NAWQA Chief Scientist}

U.S. Geological Survey

12201 Sunrise Valley Drive, MS 413

Reston, VA 20192-0002

Email: nawqapublicinfo@usgs.gov WEB: http://water.usgs.gov/nawqal

ISSN 2327-6916 (print)

ISSN 2327-6932 (online)

http://dx.doi.org/10.3133/fs20163078 